\title{
Developmental changes of the light intensity threshold for school formation in the striped jack Pseudocaranx dentex
}

\author{
T. Miyazaki ${ }^{1, *}$, S. Shiozawa ${ }^{2}$, T. Kogane ${ }^{2}$, R. Masuda ${ }^{1, * *}$, \\ K. Maruyama ${ }^{2}$, K. Tsukamoto ${ }^{1}$ \\ 'Ocean Research Institute, University of Tokyo, Minamidai, Nakano, Tokyo 164-0014, Japan \\ ${ }^{2}$ Goto Station, Japan Sea-Farming Association, Arakawa, Tamanoura, Minamimatsura, Nagasaki 853-0501, Japan
}

\begin{abstract}
Light intensity thresholds for school formation were examined in 3 stages $(20,65$, and $120 \mathrm{~mm}$ ) of striped jack Pseudocaranx dentex juveniles with behavioural and histological approaches. Behaviour under a light intensity of 300 to $10^{-5} \mathrm{~lx}$ was recorded using a video camera, and schooling behaviour, swimming speed, and nearest neighbour distance were analyzed. The retina of fish adapted to each light intensity was histologically examined. The light intensity threshold for schooling behaviour in 20 and $65 \mathrm{~mm}$ fish was $5 \times 10^{-2} \mathrm{~lx}$, while that of $120 \mathrm{~mm}$ fish was $5 \times 10^{-4} \mathrm{~lx}$. The adaptation ratio, defined as the percentage of cone cell movement, ranged from 30 to $80 \%$, corresponding with $10^{-3}$ to $1 \mathrm{~lx}$ of light intensity in $120 \mathrm{~mm}$ fish, while $20 \mathrm{~mm}$ fish showed a much narrower range of adaptation ratio, i.e. from 50 to $70 \%$. Visual acuity increased exponentially with fish total length from 20 to $120 \mathrm{~mm}$, corresponding with the increase of eye diameter. The higher range of adaptation ratio in $120 \mathrm{~mm}$ fish should enable them to recognize other fish even under low light intensity conditions and make their light intensity threshold for schooling lower than that of smaller fish. Establishment of behavioural and histological adaptability to lower light intensity should have relevance to the habitat shift that occurs in this juvenile stage from bright shallow reef pelagic waters to the offshore dark deeper area.
\end{abstract}

KEY WORDS: Pseudocaranx dentex - Carangidae S Schooling behaviour - Light intensity threshold Visual acuity $\cdot$ Behavioural ontogeny $\cdot$ Habitat shift

\section{INTRODUCTION}

The schooling behaviour of fish has various ecological values, such as protection against predators, enhancing prey detection and providing opportunities for social learning (reviewed by Parr 1927, Shaw 1962, 1970, Pitcher \& Parrish 1993). In most cases vision is the predominant sensory system used for forming and maintaining schools (Partridge \& Pitcher 1980)

Fish visual acuity is reduced under low light intensity conditions (Brunner 1934, Nakamura 1968, Vin-

\footnotetext{
Present addresses

- National Institute of Radiological Sciences, Isozaki, Hitachinaka, Ibaraki 311-1202, Japan.

E-mail: t_miyazaki@nirs.go.jp

-The Oceanic Institute, Waimanalo, Hawaii 96795-1820, USA
}

yard \& O'Brien 1976, Confer et al. 1978, Schmidt \& O'Brien 1982, Miyazaki \& Nakamura 1990, McMahon \& Holanov 1995). Under low light intensity, members in the school find it difficult to recognize each other, and thus their ability to maintain the school is probably reduced.

The light intensity threshold for school formation has been reported for several species (Table 1). These thresholds vary widely from 2.1 to $10^{-5}$ lx depending on the species. This variation in the threshold is probably caused by differences in retinal sensitivity (Tamura et al. 1957, Kobayashi 1972) and/or fish size and stage (Kitamura 1990). Few, if any, researchers have focused on the developmental changes of light intensity threshold in school formation.

Generally, eyes change from photopic to scotopic vision as light intensity decreases, and fish present 
Table 1 Light intensity threshold for schoolıng behaviour in various species. TL: total length; SL: standard length

\begin{tabular}{|c|c|c|c|c|}
\hline Species & Fish size & Threshold & Source & Converted to $\mathrm{lx}$ \\
\hline Oncorhynchus spp. & $39-34 \mathrm{~mm}$ & $10^{-4} \mathrm{ft}-\mathrm{c}$ & Ali (1959) & $10^{3} \mathrm{Lx}^{\mathrm{d}}$ \\
\hline Menidia sp. & $12-18 \mathrm{~mm}$ & $0.05 \mathrm{tt}-\mathrm{c}$ & Shaw $\{1961\}$ & $0.51 x^{a}$ \\
\hline Astyanax mexicanus & $75 \mathrm{~mm} \mathrm{TL}$ & $10^{-6} \mathrm{ft}-\mathrm{c}$ & John (1964 & $10^{-5} \mathrm{~lx}^{\mathrm{d}}$ \\
\hline Trachurus symmetricus & $105-141 \mathrm{~mm} \mathrm{SL}$ & $6 \times 10^{-6}-6 \times 10^{-7} \mathrm{ft}-\mathrm{L}$ & Hunter (1968) & $3.5 \times 10^{-5} \mathrm{~lx}^{b}$ \\
\hline Pranesus insularum & $20-60 \mathrm{~mm} \mathrm{SL}$ & $2.1 \times 10^{-1} \mathrm{ft}-\mathrm{c}$ & Major (1977) & $2.1 \mathrm{~lx}^{\mathrm{a}}$ \\
\hline Engrauhs mordax & $98-105 \mathrm{~mm} \mathrm{SL}$ & $6 \times 10^{-11} \mathrm{~W} \mathrm{~cm}^{-2}$ & Hunter \& Nicholl (1985) & $2.6 \times 10^{-}$ \\
\hline Scomber scombrus & $315-341 \mathrm{~mm}$ & $1.8 \times 10^{-7} \mu \mathrm{E} \mathrm{m}^{-2} \mathrm{~s}^{-1}$ & Glass et al. (1986) & $10^{-5} l x^{d}$ \\
\hline Brevoortia patronus & $19-22 \mathrm{~mm} \mathrm{SL}$ & $5 \times 10^{-3} \mu \mathrm{E} \mathrm{m}^{-2} \mathrm{~s}^{-1}$ & Higgs \& Fuiman (1996) & $2.8 \times 10^{-1} \mathrm{~lx}^{\mathrm{d}}$ \\
\hline
\end{tabular}

their best visual acuity when they have photopic vision. Since school formation requires precise visual acuity, the light intensity at which retinal photomechanical response occurs may affect the threshold of this behaviour. Visual acuity and retinal sensitivity improve as fish grow (reported by Ali 1959, Blaxter \& Jones 1967, Li et al 1985, Pankhurst \& Montogomery 1990, Miyazaki 1993, Pankhurst et al. 1993, Flamarique \& Hawryshyn 1996, reviewed by Douglas \& Djamgoz 1990). The light intensity threshold of schooling is therefore expected to decrease as fish grow

The object of this study is to investigate the developmental changes of the light intensity threshold for schooling behaviour in the striped jack, which is an important commercial carangid fish in Asia and Oceania, particularly highly prized in Japan (Masuda \& Tsukamoto 1998a) Underwater observations have revealed that juveniles larger than $40 \mathrm{~mm}$ in length usually form a school of 10 to 100 individuals, occasionally associating with floating objects or reefs in coastal areas, and that adults are caught from offshore waters of about $30 \mathrm{~m}$ depth or deeper (Masuda et al. 1993, 1995a). Little is known, however, about their ecology until they reach $40 \mathrm{~mm}$.

We previously observed that striped jack do not school when their vision is impaired (Masuda et al. 1995b). This was in contrast to saithe Pollachius virens (Pitcher et al, 1976) or coho salmon Oncorhynchus kisutch (Azuma \& Iwata 1994), which can join schools using only their lateral line systems. Exclusive dependence on vision in the striped jack may reflect the high visibility of their habitat in sub-tropical waters (Masuda ot al. 1903, 1995a).

In the present study, schooling behaviour was compared under various light intensities in 3 different size groups, i.e. the 20,65 , and $120 \mathrm{~mm}$ groups. These size groups are ecological significant for the relation to drift in offshore currents, recruitment to coastal areas, and habitat shift from shallow water to offshore reefs, respectively (Masuda et al. 1993, 1995a, Masuda \& Tsukamoto 1999). Development of visual acuity and the retinomotor response were also examined histologically in these stages. Based on these laboratory experiments and previous behavioural, histological, and field data, the ecology of the juvenile striped jack is discussed with special emphasis on the light intensity in their habitat.

\section{MATERIALS AND METHODS}

Fish husbandry. Striped jack juveniles were reared at the Goto Station of the Japan Sea-Farming Association (JASFA) in Nagasaki Prefecture, Japan, in 1993 and 1994. Eggs were stripped from wild caught parents (580 $\mathrm{mm}$ total length [TL] on average), fertilized, and maintained in a $0.5 \mathrm{~m}^{3}$ polycarbonate tank. Larvae hatched out $40 \mathrm{~h}$ after the fertilization and were transferred to an indoor concrete rearing pond $\left(80 \mathrm{~m}^{3}\right) 2 \mathrm{~d}$ after hatching. Rotifers Brachionus plicatilis and Artemia salina nauplii were fed on Days 3 to 40 ( 3.5 to $20 \mathrm{~mm} \mathrm{TL}$ ) and 20 to 40 ( 8 to $20 \mathrm{~mm} \mathrm{TL})$, respectively, and formula diet (Nissui Co. Ltd) was also provided from age 25 d onwards $(10 \mathrm{~mm} \mathrm{TL}$ ) Juveniles over $35 \mathrm{~mm}$ TL were transferred to netcages in the sea and were fed with formula diet. The water temperature of the indoor tank was maintained at 22 to $24^{\circ} \mathrm{C}$, and the seawater temperature ranged from 16 to $28^{\circ} \mathrm{C}$. Experiments were conducted for 3 sizes of fish of about $20 \mathrm{~mm}(21.0 \pm 3.1 \mathrm{~mm}$, mean \pm $\mathrm{SD}), 65 \mathrm{~mm}(64.1 \pm 4.1 \mathrm{~mm})$, and $120 \mathrm{~mm}(119.3 \pm$ $56 \mathrm{~mm}$ ) TT

Experimental protocol. We used 3 different sizes of experimental tanks depending on the size of the fish; 10,200 , or 500 l circular polycarbonate tanks 130, 85, or $117 \mathrm{~mm}$ diameter at the bottom) were set in a dark room (1.8 $\mathrm{m}^{2}$ area and $1.8 \mathrm{~m}$ height) with a water depth of 10,30 , or $30 \mathrm{~cm}$ for 20,65 ; or $120 \mathrm{~mm}$ fish, respec- 
tively. Illumination was provided by 10 incandescent bulbs ( 40 or $100 \mathrm{~W}$ ). With this lighting, the light spectrum is dominated ( 70 to $80 \%$ ) by a wavelength of 550 to $600 \mathrm{~nm}$ at $50 \mathrm{~cm}$ depth (Koike 1989). Tanks were covered by opal-colored vinyl sheets, the spectral transmission of which was 27.5 to $71.5 \%$ for the 400 to $700 \mathrm{~nm}$ wavelength and 52.5 to $57.5 \%$ for the 550 to $600 \mathrm{~nm}$ wavelength (Hayashi et al. 1992) There was a linear relation between the number of sheets and light intensity attenuation. Light intensities of $300,1,10^{-1}$, $10^{-2}, 10^{-3}, 10^{-4}$, or $10^{-5} \mathrm{~lx}$ were thus obtained by changing the number of vinyl sheets from 1 to 25 . Light intensity from 300 to $10^{-2}$ lx was measured at 5, 15, or $15 \mathrm{~cm}$ depth in the center of each tank by an underwater illuminance meter (ALM-1; wavelength range: 300 to $680 \mathrm{~nm}$, peak wavelength: $620 \pm 20 \mathrm{~mm}$, measuring range: $10^{-2}$ to $10^{5} \mathrm{~lx}$, Alec Co.); extrapolated values were used for light intensities of $10^{-3}, 10^{-4}$, or $10^{-5} \mathrm{~lx}$. In this study, Ix was used as the light intensity unit. The retinas of fish living at 5 to $30 \mathrm{~m}$ depth are reported to be most sensitive to the 550 to $600 \mathrm{~nm}$ wavelength (Kobayashi 1972). Our illuminance meter covered this range. For video recording, infrared light was provided by an incandescent bulb fitted with an infrared filter (Fuji film IR-78, cut below $730 \mathrm{~nm}$, peak above $870 \mathrm{~nm}$, Fuji Film Co.). This light, invisible to fish, was kept on throughout the duration of our experiments. Infrared radiation enabled us to observe the fish as dark silhouettes against the light background of the tank wall or bottom. Video recording was conducted by a Handy Cam CCD-V700 (SONY Co.) for 300 and $1 \mathrm{~lx}$ illumination or by a Night Viewer C3100 equipped with a CCD C3077 (HAMAMATSU Photonics Co.) for light intensity lower than $1 \mathrm{~lx}$. The video camera was set above the centre of the tank, so the experimental video records were made in 2 -dimension. The temperature of the experimental tanks was maintained the same as in the rearing tanks, ranging from 19.3 to $23.0^{\circ} \mathrm{C}$ using a water bath (10 l tank) or by exchanging water at a rate of $80 \mathrm{ml} \mathrm{s}^{-1}$ (200 and $500 \mathrm{l}$ tanks).

Ten fish (the minimum number in a school observed in the wild; Masuda \& Tsukamoto 1999) in each size group were put in the appropriate size tank and were acclimated to the tank at $300 \mathrm{~lx}$ for $1 \mathrm{~h}$. To confirm that the school collapses in complete darkness, light intensity was reduced to $0 \mathrm{~lx}$ for $3 \mathrm{~min}$, and then to confirm that the fish can form schools when they have enough light, the light intensity was raised to $300 \mathrm{~lx}$ for $2 \mathrm{~min}$. After this initial procedure, each light intensity was tested for $30 \mathrm{~min}$ to find the light intensity threshold (light intensity profile is showed in Fig.1).

Video analysis. Schooling behaviour was analyzed from the video record of the last $10 \mathrm{~min}$ at each light intensity. We measured schooling threshold, swimming speed, and nearest neighbour distance (NND).

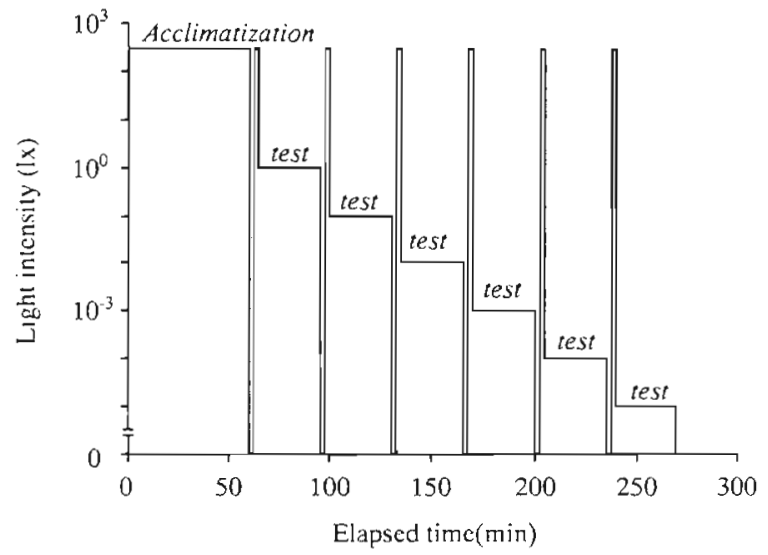

Fig. 1. Light intensity profile of the present experiment

In our study we considered fish to have presented 'schooling' behaviour when $50 \%$ of the fish swam in the same direction. At each light intensity a 2 min record was sampled twice, and the percentage of schooling duration was measured and defined as the 'schooling rate'. Average schooling rates in 3 trials were compared using a t-test.

Swimming speed was calculated by measuring the time needed to pass a line on the video monitor. The mean total length of the group of each experiment was divided by the time required to pass through the line, and swimming speed was thus obtained. Swimming speed was measured 100 times at each light intensity level by stopping the video record and arbitrarily selecting a fish from 10 fish in the monitor for 100 times, and the mean and standard deviation were calculated. The mean swimming speed for each light intensity was obtained from 3 replicates and compared among different light intensities by ANOVA followed by Bonferroni's test (Howell 1997) using Stat View J-4.51.1

For each fish, the distance between its snout and the snouts of the nearest neighbours was measured, and the mean of 10 measurements was recorded as the NND (mm) on the frame. NND was measured 10 times for each light level, and the mean and standard deviations of 100 sets of data were calculated. The mean NND of 3 replicate tanks was obtained at each light intensity level and was compared by ANOVA followed by Bonferroni's test.

Histological analysis of vision. Fish were acclimated to each light intensity ( 300 to $10^{-5} \mathrm{~lx}$ ) for $1 \mathrm{~h}$ (in previous studies salmonid fish Oncorhynchus spp. were acclimated for 50 min [Ali 1959], jack mackerel Trachurus japonicus for $60 \mathrm{~min}$ [Arimoto et al. 1988]). They were then decapitated after anesthesia treatment, and their heads were fixed immediately in Bouin's solution. Eyeballs were enucleated after 24 to $48 \mathrm{~h}$ of fixation, and eyeball and lens diameters were measured. Each retina was dissected into $5 \mathrm{~mm}$ squares, embedded in paraf- 
fin, sectioned transversely at 4 to $7 \mu \mathrm{m}$ thickness, and stained with haematoxylin and eosin. To estimate the light and dark adaptation level of the retina, the index of 'adaptation ratio' was applied based on the cone migratory position in the retina (Zhang et al. 1993). The distance between the cone ellipsoid and retinal pigment epithelium, and between the outer limiting membrane and retinal pigment epithelium, were measured. The ratio of the former to the latter was defined as the adaptation ratio. The light-adapted retina which was fixed under the natural light condition of daytime (about $10^{5}$ lx) was also sectioned tangentially and stained. The visual acuity (VA) in each size group was calculated from the number of cone cells per $100 \mu \mathrm{m}$ length of retina and the lens focal distance by the following formula of Neave (1984):

$$
\begin{gathered}
\sin \alpha=1.11 /(10 d \times F) \\
\mathrm{VA}=1 /[\alpha \times(180 / \pi) \times 60]
\end{gathered}
$$

where $\alpha$ (radian) is the minimum separable angle, $F$ is the focal distance of the lens estimated from the lens radius ( $r, \mathrm{~mm}$ ) using Matthiessen's ratio, and $d$ is the density of cones, with adjustment for shrinkage. Matthiessen's ratio varies from 2.2 to 2.8 depending on fish species and size (Fernald 1990). We used 2.5 in our study $(F=2.5 r)$. For the estimation of adaptation ratio and visual acuity, a $5 \mathrm{~mm}$ square of retina was dissected from the dorso-temporal region, since cone density was lowest in this area (Miyazaki et al. unpubl.).

\section{RESULTS}

\section{Typical behaviour in the experimental tank}

Three typical patterns of schooling behaviour were observed. One is that of the well-formed 'school' (Fig. 2a). Individual fish occasionally left the school but immediately rejoined it. The spread and contraction of school size was repeated irregularly. The school was observed under high light intensities $(\geq 1 \mathrm{~lx})$. The second pattern is 'aggregation', which occurred when all the fish gathered but their orientation was random (Fig. 2b). Aggregation was most irequently observed under low light levels from $10^{-1}$ to $10^{-3} \mathrm{~lx}$. We labeled the third pattern 'random movement', and it was typically observed in darkness (Fig. 2c). 1ll fish moved in
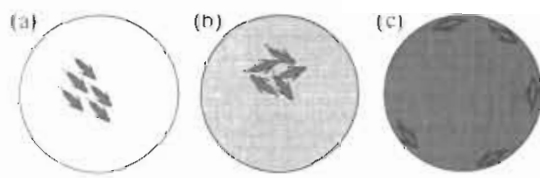

Fig. 2. Pseudocaranx dentex. Three typical patterns of schooling behaviour observed at different light intensity levels random directions, swimming along the tank wall Their swimming direction was not biased in a clockwise $(52 \%)$ or counterclockwise $(48 \%)$ direction (not significantly different in Mann-Whitney's $U$-test, $\mathrm{p}=$ $0.186, \mathrm{n}=30$ ). Fish occasionally swam across the center of the tank but resumed this circular swimming along the wall after encountering the wall.

\section{Light intensity threshold for schooling behaviour}

In $20 \mathrm{~mm}$ fish, schooling was observed at 300,1 , and $10^{-1}$ ix with a relatively low schooling rate of $40.0,39.1$, and $24.3 \%$, respectively (Fig. $3 a$ ). At $10^{-2}$ and $10^{-3}$ ]x $20 \mathrm{~mm}$ fish did not form schools and showed random movement. These results indicated that the light intensity threshold for schooling of $20 \mathrm{~mm}$ fish exists between $10^{-1} \mathrm{~lx}$ and $10^{-2} \mathrm{~lx}$, and thus we conventionally regarded their threshold as $5 \times 10^{-2} \mathrm{~lx}$. In $65 \mathrm{~mm}$ fish, the schooling rate was $94.6 \%$ at $300 \mathrm{~lx}, 89.6 \%$ at $1 \mathrm{~lx}$, and $83.1 \%$ at $10^{-1} \mathrm{~lx}$; these values were more than twice as high as those of $20 \mathrm{~mm}$ fish at each light intensity. At $10^{-2} \mathrm{~lx}$, schooling collapsed. The threshold of $65 \mathrm{~mm}$ fish was expected to be between $10^{-1}$ and $10^{-2} \mathrm{~lx} ; 5 \times 10^{-2} \mathrm{~lx}$ was considered to be their threshold Fish of $120 \mathrm{~mm}$ size showed compact schooling along
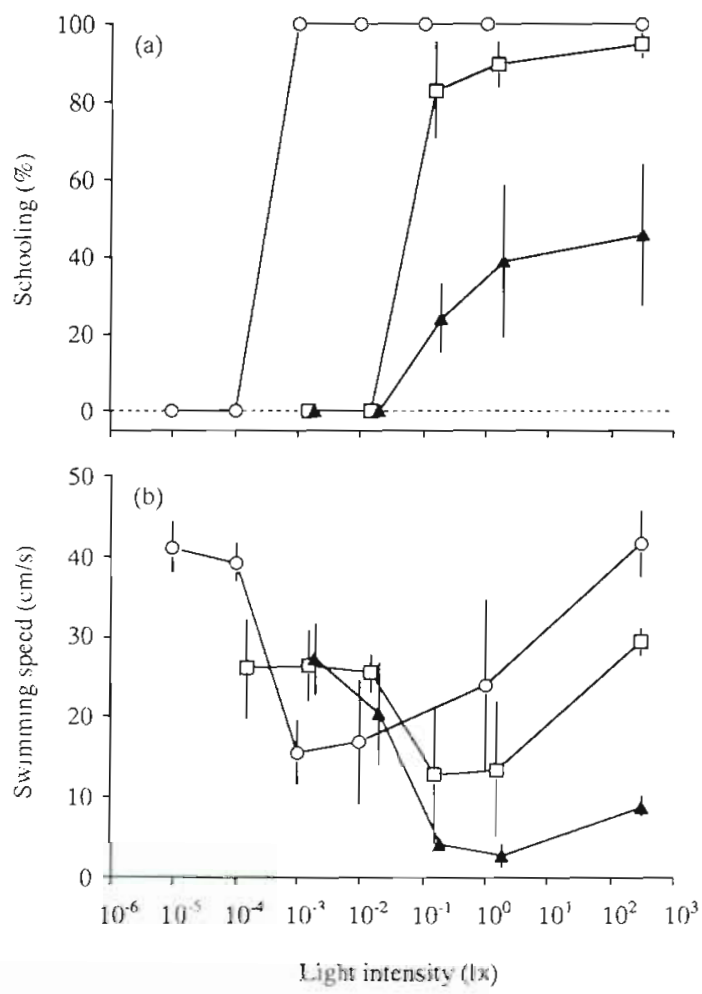

Fig. 3. Pseudocaranx dentex (a) Schooling rate and (b) swimming speed under different light intensities. (o) $120 \mathrm{~mm}$. (D) $65 \mathrm{~mm}$, and $(\Delta) 20 \mathrm{~mm}$ fish; vertical bars indicate standard deviation 
Table 2. Pseudocaranx dentex. Nearest neighbour distance (NND; mm) at different light intensity levels in each size group. RM: random movement

\begin{tabular}{|c|c|c|c|c|c|}
\hline \multirow[t]{2}{*}{$\mathrm{bx}$} & \multicolumn{4}{|c|}{ Average $\pm S D(\mathrm{~mm})$} & \\
\hline & $20 \mathrm{~mm}$ & & $65 \mathrm{~mm}$ & $120 \mathrm{~mm}$ & \\
\hline 300 & $28.5 \pm 9.8$ & & $83.0 \pm 16.5$ & $117.8 \pm 10.6)$ & \multirow{5}{*}{$p<0.025$} \\
\hline 1 & $18.4 \pm 2.7$ & $p<0.036$ & $81.5 \pm 8.6$ & $103.3 \pm 5.1$ & \\
\hline $10^{-1}$ & $15.5 \pm 1.4$ & & $87.5 \pm 9.5$ & $-{ }^{a}$ & \\
\hline $10^{-2}$ & $R M$ & & RM & $124.5 \pm 7.3$ & \\
\hline $10^{-3}$ & RM & & RM & $111.5 \pm 13.0$ & \\
\hline \multicolumn{6}{|c|}{${ }^{\circ}$ Experiment not conducted } \\
\hline
\end{tabular}

( $\mathrm{p}<0.025$ between 1 and $10^{-2} \mathrm{~lx}$ in Bonferroni's test).

\section{Visual acuity and adaptation ratio}

Both eye diameter and lens diameter increased as fish grew (Fig. 4a,b). Cone cell density decreased until fish reached a TL of $90 \mathrm{~mm}$, and thereafter it remained at a constant value of about 11/0.01 mm length (Fig. 4c). Visual acuity rapidly increased from the wall (schooling rate, $100 \%$ ) when the light intensity was between 300 and $10^{-2} \mathrm{~lx}$. At $10^{-3} \mathrm{~lx}$ intensity, they tended to form a school at the center of the tank rather than along the wall, but they still maintained the school. At $10^{-4}$ and $10^{-5} \mathrm{~lx}$, fish showed random movement, indicating that the threshold of $120 \mathrm{~mm}$ fish should be $5 \times 10^{-4} \mathrm{~lx}$.

Fish of any size groups showed disordered swimming behaviour at first. After the 30 min acclimatization, schooling behaviour was observed and swimming speed was stabilized at about 15,40 , and $50 \mathrm{~cm} \mathrm{~s}^{-1}$ in the 20,65, and $120 \mathrm{~mm}$ fish, respectively. At a test light intensity of $300 \mathrm{~lx}$, the average swimming speed was $8.6 \mathrm{~cm} \mathrm{~s}^{-1}\left(4.3 \mathrm{TL} \mathrm{s}^{-1}\right), 29.3 \mathrm{~cm} \mathrm{~s}^{-1}\left(4.5 \mathrm{TL} \mathrm{s}^{-1}\right)$, and $41.5 \mathrm{~cm} \mathrm{~s}^{-1}\left(3.5 \mathrm{TL} \mathrm{s}^{-1}\right)$ in the 20,65 , and $120 \mathrm{~mm}$ fish, respectively. The swimming speed of all size groups decreased as light intensity decreased, until it reached the threshold; under light intensity below the threshold, swimming speed increased as the light intensity decreased (Fig. 3b).

In the 65 and $120 \mathrm{~mm}$ fish, individuals leaving the school were often observed at the light intensities of 1 , $10^{-1}$, and $10^{-2} \mathrm{~lx}$, resulting in a relatively low average and high variation in swimming speed. Swimming speed right above the threshold was $4.0 \mathrm{~cm} \mathrm{~s}^{-1}(2.0 \mathrm{TL}$ $\left.\mathrm{s}^{-1}\right), 12.8 \mathrm{~cm} \mathrm{~s}^{-1}\left(2.6 \mathrm{TL} \mathrm{s}^{-1}\right)$, and $15.6 \mathrm{~cm} \mathrm{~s}^{-1}\left(1.1 \mathrm{TL} \mathrm{s}^{-1}\right)$ in the 20,65 , and $120 \mathrm{~mm}$ fish, respectively. These values were significantly smaller than the swimming speed at $300 \mathrm{~lx}$ ( $t$-test, $\mathrm{p}<0.0001$ ). Swimming speed was significantly higher at light intensities below the threshold compared to intensities right above the thresholds $(\mathrm{p}<0.0007$ in $120 \mathrm{~mm}, \mathrm{p}<0.05$ in $65 \mathrm{~mm}$, $\mathrm{p}<0.012$ in $20 \mathrm{~mm}$ fish, Bonferroni's test). When light intensity was below the threshold, fish occasionally collided with the wall, so the variance of swimming speed was large at these levels.

NND decreased slightly in accordance with the decrease in light intensity in the $20 \mathrm{~mm}$ fish (Table 2; Bonferroni's test, $p<0.036$ between 300 and $10^{-1} \mathrm{~lx}$ ). In the $65 \mathrm{~mm}$ and $120 \mathrm{~mm}$ size groups NND did not show this tendency, although $120 \mathrm{~mm}$ fish showed a slightly smaller NND at $1 \mathrm{~lx}$ compared to other light intensities
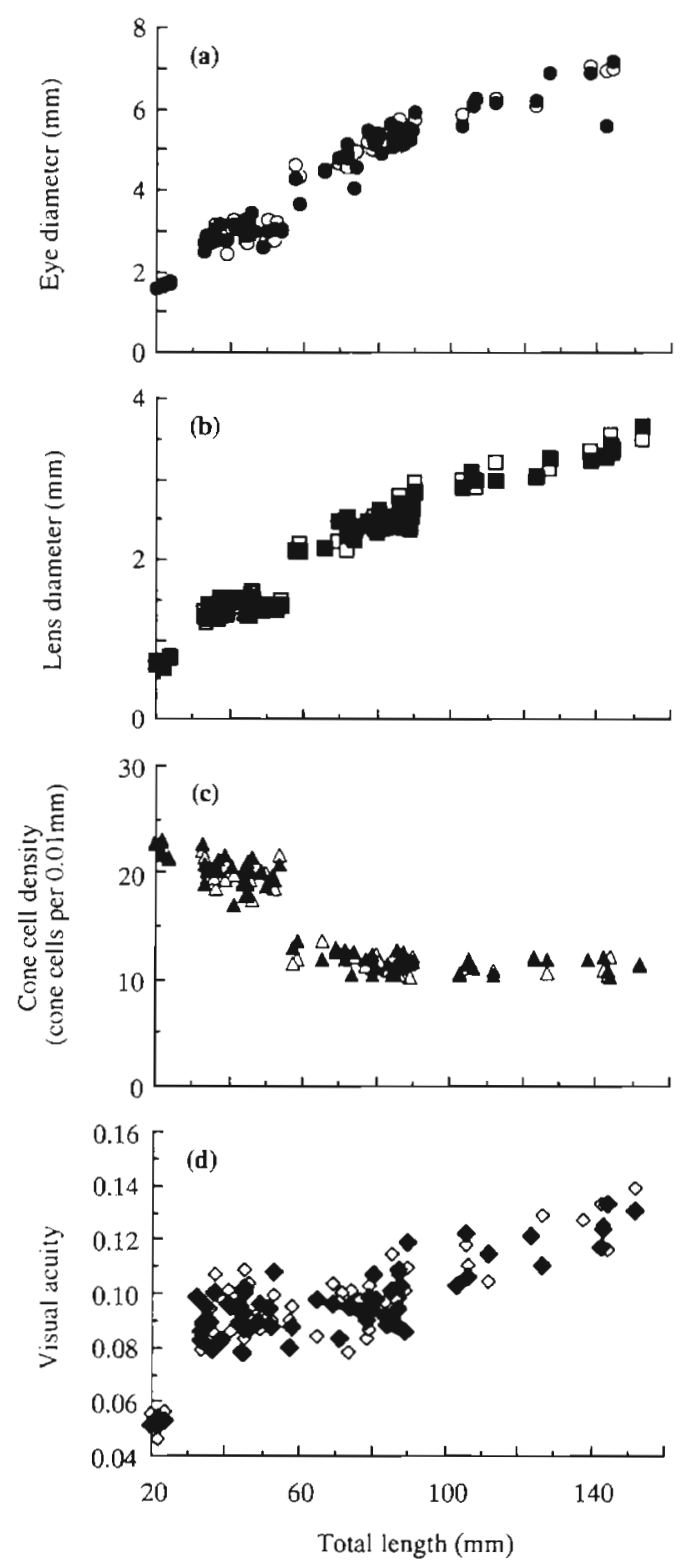

Fig. 4. Pseudocaranx dentex. Developmental changes in (a) eye diameter, (b) lens diameter, (c) cone density, and (d) visual acuity. Open symbols: right eye filled symbols: left eye 


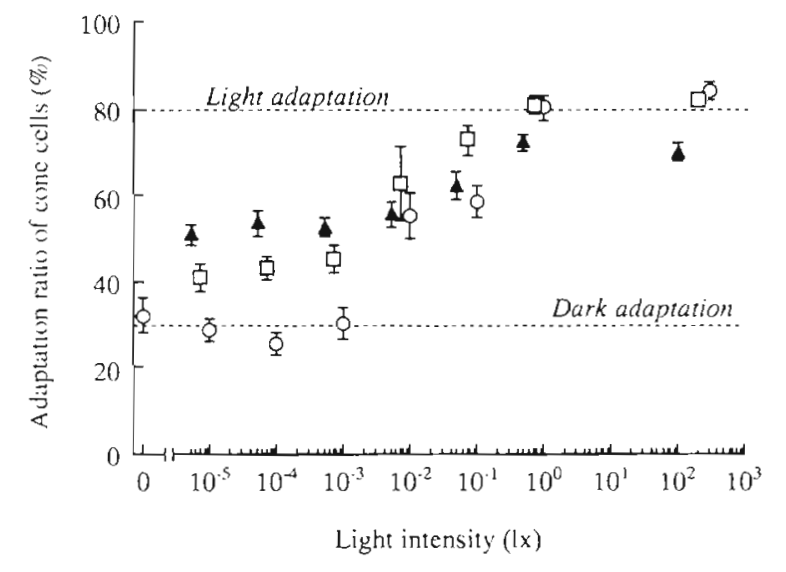

Fig. 5. Pseudocaranx dentex. Retinal adaptation of striped jack in (o) $120 \mathrm{~mm}$, () $65 \mathrm{~mm}$, and (4) $20 \mathrm{~mm}$ fish

20 to $30 \mathrm{~mm}$, and after that it increased almost linearly with growth (Fig. 4d)

In the $120 \mathrm{~mm}$ fish, the adaptation ratio at 300 and $1 \mathrm{~lx}$ was 84 and $80 \%$, respectively, which was not significantly different; the ratio decreased to $10^{-3} \mathrm{~lx}$ and kept a constant value of about $30 \%$ at $10^{-3}$ to $10^{-5} \mathrm{~lx}$ (Fig. 5). It was noteworthy that the value was also $30 \%$ even at $0 \mathrm{~lx}$. These results suggested that the adaptation ratio of the retina in the $120 \mathrm{~mm}$ striped jack was $80 \%$ at light-adaptation and $30 \%$ at dark-adaptation, respectively, and that they fully adapted to dark conditions at about $10^{-3} \mathrm{~lx}$. In $20 \mathrm{~mm}$ fish, the adaptation ratio was not different between 300 and $1 \mathrm{~lx}$; it decreased from 1 to $10^{-3} \mathrm{~lx}$, and it remained constant

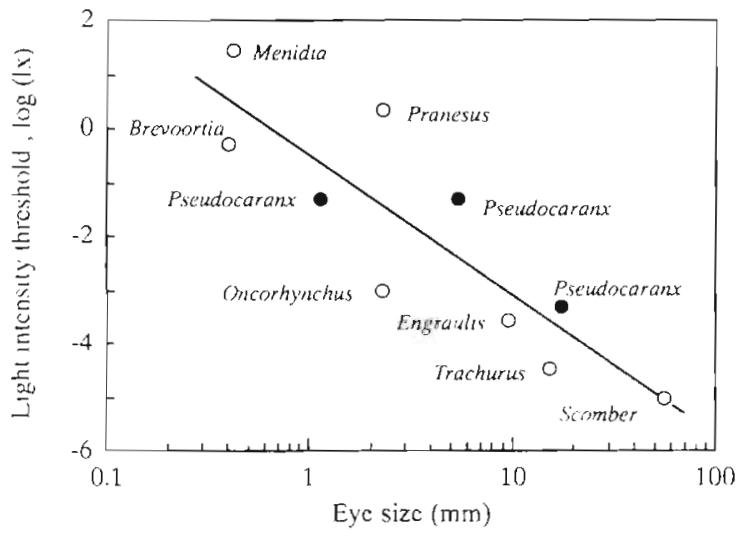

Fig. 6. Relationship between eye size and light intensity threshold of schooling. ( Present study, (0) previous studies. Oncorhynchus spp. (Ali 1959), Menidia sp. (Shaw 1961), Tra-

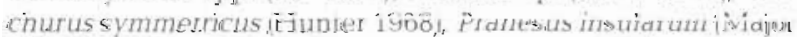
19771. Engraulis mordax (Hunter \& Nicholl 1985), Scomber scombrus (Glass et a1. 1986), Brevoortia patronus (Higgs \& Fuiman 1996). Values of eye size in previous studies were redrawn from Higgs \& Fuiman (1996). Thresholds were converted to $\mid x$ (see Table 1 ) and changed to $\log$ scale $(\log (L T)=$ $-0.51-2.60 \mathrm{log}(r)$; where $\mathrm{LT}=$ light intensity threshold, and $r=$ eye size, correlation coefficient 0.87 ) thereafter. Their adaptation ratio, however, was lower at Jight-adaptation and higher at dark-adaptation compared with that of the $120 \mathrm{~mm}$ fish. As for $65 \mathrm{~mm}$ fish, the pattern of the adaptation ratio for light intensity was similar to that of $120 \mathrm{~mm}$ fish.

\section{DISCUSSION}

\section{Developmental changes in vision and schooling behaviour}

The light intensity threshold for schooling decreased from $10^{-2}$ to $10^{-4} \mathrm{Ix}$ as fish size increased from 65 to $120 \mathrm{~mm}$ (Fig. 3a). If the threshold is affected only by vision, this can be attributed to the development of (1) visual acuity, (2) retinal sensitivity, and (3) eye size.

Visual acuity, which is closely related to schooling behaviour, increased from 0.05 to 0.11 as fish size increased from 20 to $120 \mathrm{~mm}$ (Fig. 4d). With these visual changes the maximum distance at which individuals could recognize each other was estimated to increase from 3.4 to $45.4 \mathrm{~m}$ in the same period $(D=(\phi \times$ $V A \times 180 \times 60) \pi^{-1}$; where $D=$ distance, $0=$ size of other fish, $\mathrm{VA}=$ visual acuity). The chance of losing sight of school members will thus decrease with growth. Retinal sensitivity to light stimuli increases rapidly with the development of rod cells and their increase in density (Guma'a 1982, Kawamura et al. 1984). In striped jack, rod cell formation was confirmed at $1.2 \mathrm{~mm}$ IL (Masuda $\&$ Tsukamoto 1996). Due to the appearance of rod cells, the striped jack's retinal sensitivity should increase significantly, enabling them to see each other while schooling even at low light intensity conditions.

Higgs \& Fuiman (1996) summarized the relation between eye size (the square of eye radius) and light intensity threshold for schooling in several species and found that there is a strong correlation between these parameters (Fig. 6). Present data for striped jack fit this correlation well. These inter-and intraspecies comparisons support the assumption that eye size is the important determinant factor for the light intensity thresholds of school formation.

In coho salmon juveniles $(130 \mathrm{~mm}$ TL), NND increased as light intensity decreased, suggesting that low visual acuity under the dark adaptation negatively impacts vision and schooling (Azuma \& Iwata 1994). In our experiment such a tendency was observed only in the $90 \mathrm{~mm}$ fich but not in 6.5 or $120 \mathrm{~mm}$ fish. This discrepancy may be attributed to species-and/or stagespecific characteristics.

The schooling rate was higher in the larger fish (Fig. 3a). The lower schooling rate in $20 \mathrm{~mm}$ fish group may be due to (1) immature schooling behaviour, (2) difference in light intensity preference, and/or (3) differ- 
ence in schooling motivation under the experimental condition. Striped jack are known to school at about $16 \mathrm{~mm}$ TL, and their NND decreases gradually until they reach the size of $30 \mathrm{~mm}$ (Masuda \& Tsukamoto 1998b). Although buccal lateral lines were complete at $18 \mathrm{~mm}$, trunk lateral lines were only formed from 20 to $30 \mathrm{~mm}$ (Masuda \& Tsukamoto 1996). Therefore at $20 \mathrm{~mm}$, schooling behaviour might not be fully matured. Retinal sensitivity to light stimuli might be different depending on size, which may well result in the light intensity preference. Striped jack juveniles at 12, 20, or $28 \mathrm{~mm} \mathrm{TL}$ preferred $10^{4} \mathrm{~lx}$ compared to $10^{3}$ or $10^{5} \mathrm{~lx}$ (Masuda \& Tsukamoto 1996). Although we have no data on the light intensity preference of striped jack larger than $28 \mathrm{~mm}$, 65 and $120 \mathrm{~mm}$ fish may well have lower light intensity preferences, since retinal sensitivity of fish generally increases along with retina development (Blaxter \& Jones 1967. Kawamura et al. 1984, Champalbert et al. 1991). Given this, $20 \mathrm{~mm}$ fish could have shown a higher schooling rate at light intensities above $300 \mathrm{Lx}$

We used a water bath for $20 \mathrm{~mm}$ fish and circulation systems for 65 and $120 \mathrm{~mm}$ fish. The presence of water circulation in the larger group may have induced higher rates of schooling. However, it is not sensible to attribute the collapse of schooling to the presence or absence of circulation, since $20 \mathrm{~mm}$ fish resumed their schooling behaviour when light intensity was recovered to $300 \mathrm{~lx}$. Further experiments will be required to understand the possible involvement of sensory organs other than the eyes.

\section{Behaviour of wild fish under low light intensity conditions}

Kobayashi (1972) reported that fish living at 5 to $30 \mathrm{~m}$ depth have maximum luminous efficiency of the retina at 550 to $600 \mathrm{~nm}$, which is equal to the maximum wavelength transmitting in coastal water (Jerlov 1967). Although we have no information about the spectral luminous efficiency in the striped jack, we presume that this species has the same characteristics as other coastal species. Fig. 7 shows the relationship between depth and the attenuation coefficient $\left(k=0.088 \mathrm{~m}^{-1}\right)$ measured in the sea off the Goto Station, JASFA $\left(33^{\circ} \mathrm{N}\right.$, $\left.129^{\circ} \mathrm{E}\right)$. As we consider light intensity as the major component of light attenuation, the underwater light intensity at the depth of $5 \mathrm{~m}$ is about $13 \%$ of that at the surface. Since the light intensity at the sea surface under a full moon is about $5 \times 10^{-1} \mathrm{~lx}$ (US Navy Illuminance Chart [1952] referred to by Glass et al. [1986]), it is estimated to be about $6.5 \times 10^{-2} \mathrm{~lx}$ at $5 \mathrm{~m}$ depth and about $5.1 \times 10^{-4} \mathrm{~lx}$ at $60 \mathrm{~m}$ depth (Jerlov 1967: $I_{\mathrm{m}}=I_{0} \times$ $\exp (-k m)$; where $I_{\mathrm{m}}$ and $I_{0}=$ the illuminance at meter depth, $m$, and the sea surface, respectively). Present

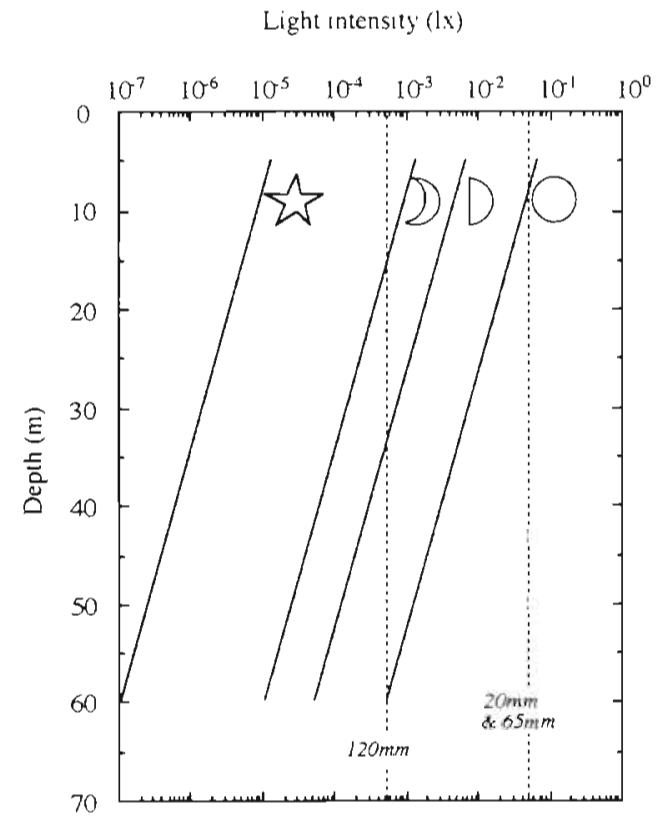

Fig. 7 Distribution of the light intensity in the sea estimated from the attenuation coefficient Light intensity in each moon phase was redrawn from Glass et al. (1985)

work shows that $120 \mathrm{~mm}$ striped jack can form schools at $60 \mathrm{~m}$ depth in the full moon as the light level is higher than their threshold. Similarly, the limit of depth at which they can school is estimated to be $34 \mathrm{~m}$ during a half moon night $\left(5 \times 10^{-2} \mathrm{~lx}\right.$ at the surface), and $16 \mathrm{~m}$ during a crescent moon night $\left(1 \times 10^{-2} 1 \times\right.$ at the surface). Striped jacks cannot maintain a school under new moon (star light) conditions because light intensity is only $10^{-4} \mathrm{~lx}$ even at the sea surface. Both 20 and $65 \mathrm{~mm}$ fish can school at $8 \mathrm{~m}$ or shallower under a full moon, and they cannot school under a half moon.

In the present experiment, fish swimming speed decreased when light intensity decreased. It should be difficult to continue parallel orientation under low light intensity conditions, since the striped jack maintain school by vision. Striped jack showed rapid and random swimming when light intensity was below the threshold. This might reflect their frantic condition caused by the lack of visual information about their school members. In the wild condition such a situation would be prevented in some way, since field observation revealed that the same group of striped jack remains in the same place over several nights (Masuda et al. 1993). Sogard \& Olla (1996) reported that walleye pollock juveniles migrate close to the surface, become less active, and disperse their school at night. Such vertical migration has never been observed in the striped jack.

In natural waters at night, striped jack have been observed to associate with floating objects (Masuda et al. 1993), algae, and mooring ropes (Kuwada et al. unpubl.). These behaviours, defined as association 
behaviours, have been reported in many species of fish (reviewed by Kingsford 1993). In laboratory conditions striped jack first associate with floating objects at $12 \mathrm{~mm} T \mathrm{~L}$, show very strong association behaviour at $20 \mathrm{~mm}$, and this tendency gradually decreases later on (Masuda \& Tsukamoto 1999, Shiozawa el al. unpubl. datal. When the light intensity is not enough to maintain schooling behaviour, they might utilize this association behaviour to keep aggregation. Strong association in $20 \mathrm{~mm}$ fish might supplement their relatively high light intensity thresholds, thus preventing the dispersion of school members at night.

The life history of striped jack is summarized as follows with respect to light intensity thresholds. Striped jack of $20 \mathrm{~mm}$ size typically drift with the current, probably associating with floating objects (Masuda \& Tsukamoto 1999). At this stage their habitat is shallow water, and although their visual acuity is not as yet well developed, they can prevent dispersion at night by associating with floating objects. They migrate to coastal areas at $40 \mathrm{~mm}$ TL (Masuda et al. 1993, 1995a), and at $65 \mathrm{~mm}$ TL they are typically found at shallow shore reefs and their swimming depth is about 1 to $2 \mathrm{~m}$ (Masuda et al. 1993). Because their habitat is still shallow at this stage, they do not require a very low light intensity threshold to maintain a school. Their habitat gradually changes to deeper areas as they grow (Masuda et al. 1993); this may well be supported by the decrease in light intensity threshold shown in the present work.

We made our observations under controlled laboratory conditions using hatchery-origin juveniles. There is a possibility that experimental tank scales and hatchery conditions might have biased some of the behavioural characteristics of this species. For example, Petersen \& Gadomski (1994) reported that chinook salmon Oncorhynchus tshawytscha can swim faster in a larger tank than in a smaller tank, resulting in a lower predation rate by their predators (northern squawfish Ptychocheilus oregonesis). McCartt et al. (1997) demonstrated that wild bluegills Lepomis macrochirus switch from schooling to hiding as light intensity increases, while hatchery fish extensively hide in shade at all light levels. To understand the mechanism of how schooled wild striped jack prevent dispersion at very low light intensity as in a new moon condition, further field experiments such as tracking by acoustic tags will be required

Acknowledgements. We would like to thank 4 anonymous referees for ineir constructive criticism oi tite manusctiph.

\section{LITERATURE CITED}

Ali MA (1959) The ocular structure, retinomotor and photobehavioural responses of juvenile Pacific salmon. Can $j$ Zool $37: 96.5-996$
Arimoto T, Watanabe N. Okamoto N (1988) Retinomotor responces of jack mackerel Trachurus japonicus to light condition. J Tokyo Univ Fish 75:333-341 (in Japanese)

Azuma T, Iwata M (1994) Influence of illumination intensity on the nearest neighbour distance in coho salmon. J Fish Biol 45:1113-1118

Blaxter JHS, Jones MP (1967) The development of the retina and retinomotor responses in the herring. J Mar Biol Assoc UK 47:677-697

Breder CM Jr (1959) Studies on social grouping in fishes. Bull Am Mus Nat Hist 117:393-482

Brunner G (1934) Über die Sehscharfe der Elritze (Phoxinus laevis) bei verschiedenen Helligkeiten. Aus Zool Inst Unıv Munchen 6:297-316

Champalbert G, Nacquart-Moulin C, Patriti G, Chiki D (1991) Ontogenic variations in the phototaxis of larval and juvenile sole Solea solea L. J Exp Mar Biol Ecol 149:207-225

Confer JL, Howick GL, Corzette MH, Kramer SL, Fitzgibbon S, Landesberg $R\{1978\}$ Visual predation by planktivores. Oikos 31:27-37

Douglas RH, Djamgoz MBA (1990) The visual system of fish Chapman and Hall, London

Fernald RD (1990) The optical system of fishes. In: Douglas $\mathrm{RH}$ and Djamgoz MBS (eds). The visual system of fish Chapman and Hall, London, p 45-61

Flamarique IN, Hawryshyn CW (1996) Retinal development and visual sensitivity of young pacific sockeye salmon (Oncorbynchus nerka). J Exp Biol 199:869-882

Glass CW, Wardle CS, Mojsiewicz WR (1986) A light intensity threshold for schouling in the Atlantic mackerel Scomber scombrus. J Fish Biol 29 (Suppl A):71-81

Guma'a SA (1982) Retinal development and retinomotor responses in perch Perca fluviatilis L. J Fish Biol 20:61.1-618

Hayashi T, Yamakawa H, Matsuike K (1992) Change in phototactic response with growth of striped beakperch larvae and juvenile. Nippon Suisan Gakkaishi 58(6):1043-1047 (in Japanese)

Higgs DM, Fuiman LA (1996) Light intensity and schooling behaviour in larval gulf menhaden. J Fish Biol 48:979-991

Howell DC (1997) Statistical methods for psychology. Duxbury, Belmont

Hunter JR (1968) Effects of light on schooling and feeding of jurk mackerel Trachurus symmetricus. J Fish Res Board Can 25:393-407

Hunter J, Nicholl R (1985) Visual threshold for schooling in northern anchovy Engraulis mordax. Fish Bull 83-235-242

Jerlov NG (1967) Marine optics. Elsevier Scientific Publishing Company, New York

John KR (1964) Illumination, vision, and schooling of Astyanax mexicanus. J Fish Res Board Can 21:1453-1473

Kawamura G, Mukai Y, Ohta $H$ (1984) Change in the visual threshold with development of rods in ayu. Bull Japan Soc Sci Fish 50:2133

Kingsford MJ (1993) Biotic and abiotic structure in the pelagic environment: importance to small fishes. Bull Mar Sci 53: $393-415$

Kitamura S (1990) Changes in the retinal photosensitivity of flounder Paralichthys olivaceus during metamorphosis. Nippon Suisan Gakkaishi 56:1007

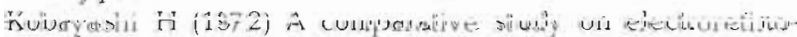
gram in fish. J Shimonoseki Coil Fish 11/3i:17-148

Koike T (1989) Studies on the behavioural response of the Japanese horse mackerel, Trunchurus japonicus, to intermittent light. Bull Fac Bioresource Mie Univ 2:23-53 in Japanese)

Li KT, Wetterer JK, Hairston NG Jr (1985) Fish size, visual res. olution, and prey selectivity. Ecology 66:1729-1735 
Major PF (1977) Predator-prey interactions in schooling fishes during periods of twilight: a study of the silverside Pranesus insularum in Hawaii. Fish Bull. US 75:415-426

Masuda R, Tsukamoto K (1996) Morphological development in relation to phototaxis and rheotaxis in the striped jack Pseudocaranx dentex. Mar Freshw Behav Physiol 28: $75-90$

Masuda R, Tsukamoto $\mathrm{K}$ (1998a) Stock enhancement in Japan: review and perspective. Bull Mar Sci 62:337-358

Masuda R, Tsukamoto K (1998b) The ontogeny of schooling behaviour in the striped jack. J Fish Biol 52:483-493

Masuda R, Tsukamoto K (1999) School formation and concurrent developmental changes in carangid fish with reference to dietary conditions. Environ Biol Fish 56:243-252

Masuda R, Tsukamoto K, Shiozawa S, Imaizumi, K (1993) Some ecological aspects of striped jack Pseudocaranx dentex in Kyushu and the Ogasawara Islands, Japan. Saibai Giken 22(1):55-65 (in Japanese)

Masuda R, Kamaishi T, Kobayashi T, Tsukamoto K, Numachi K (1995a) Mitochondrial DNA differentiation between two sympatric morphs of striped jack near Japan. J Fish Biol 46:1003-1010

Masuda R, Tsukamoto K, Arimoto M, Shiozawa S, Mizuta Y (1995b) Role of vision in schooling and association behaviour in striped jack Pseudocaranx dentex. Saibai Giken 24:53-59 (in Japanese)

McCartt AL, Lynch WE Jr, Johnson DL (1997) How light, a predator, and experience influence bluegill use of shade and schooling. Environ Biol Fish 49:79-87

McMahon TE, Holanov SH (1995) Foraging success of largemouth bass at different light intensities: implications for time and depth of feeding. J Fish Biol 46: $759-767$

Miyazaki T (1993) The change of visual acuity of larvae and juveniles of striped beakperch in accordance with their growth. Nippon Suisan Gakkaishi 59:437-440 (in Japanese)

Miyazaki T, Nakamura Y (1990) Single line acuity of 0-yearold Japanese parrotfish determined by the conditioned reflex method. Nippon Suisan Gakkaishi 56:887-892 (in Japanese)

Nakamura E (1968) Visual acuity of two tunas, Katsuwonus pelamis and Euthynnus affinis. Copeia 1:41-49

Neave DA (1984) The development of visual acuity in larval plaice (Pleuronectes platessa L.) and turbot (Scophthalmus maximus L.). J Exp Mar Biol Ecol 78:167-175

Editorial responsibility: Otto Kinne (Editor),

Oldendorf/Luhe, Germany
Parr AE (1927) A contribution to the theoretical analysis of the schooling behaviour of fishes. Occas Pap Bingham Oceanogr Colln 1:1-32

Pankhurst PM, Montgomery JC (1990) Ontogeny of vision in the Antarctic fish Pafothenia borchgrevinki (Nototheniidae). Polar Biol 10:419-422

Pankhurst PM, Pankhurst NW, Montgomery JC (1993) Comparison of behavioural and morphological measures of visual acuity during ontogeny in a teleost fish Forsrerygion varium, Tripterygiidae (Forster, 1801). Brain Behav Evol 42:178-188

Partridge BL, Pitcher TJ (1980) The sensory basis of fish schools: relative roles of lateral line and vision. J Comp Physiol 135:315-325

Petersen JH, Gadomski DM (1994) Light-mediated predation by northern squawfish on juvenile chinook salmon. J Fish Biol 45 (Suppl A):227-242

Pitcher TJ, Parrish JK (1993) Function of shoaling behaviour in teleosts. In: Pitcher TJ (ed) Behaviour of teleost fish. Chapman and Hall, London, p 363-439

Pitcher TJ, Partridge BL, Wardle CS (1976) A blind fish can school. Science 194:963-965

Schmidt D, O'Brien WJ (1982) Planktivorous feeding ecology of arctic grayling (Thymallus arcticus). Can J Fish Aquat Sci 39:475-482

Shaw E (1961) Minimal light intensity and the dispersal of schooling fish. Bull Inst Oceanogr Monaco 1213:1-8

Shaw E (1962) The schooling of fishes. Sci Am 206:128-138

Shaw E (1970) Schooling in fishes: critique and review. In: Aronson LR, Tobach E, Lehrman DS, Rosenblatt JS (eds) Development and evolution of behavior: essays in memory of TC Schneirla. WH Freeman, San Francisco, p 452-480

Sogard AM, Olla BL (1996) Diel patterns of behavior in juvenile walleye pollock, Theragra chalcogramma. Environ Biol Fish 47:379-386

Tamura T, Mitarai G, Sugita Y (1957) The lowest intensity of illumination to produce the maximum cone potential in the fish retina: its ecological meaning. Bull Jap Soc Sci Fish 23:86-91

Vinyard GL, O'Brien WJ (1976) Effects of light and turbidity on the reactive distance of bluegill. J Fish Res Board Can 33:2845-2849

Zhang $X$, Akiyama $S$, Arimoto $T$, Inoue $Y$, Matsushita $Y$ (1993) Retinal adaptation of walleye pollock in trawl fishing ground of North Pacific. Nippon Suisan Gakkaishi 59: 481-485 (in Japanese)

Submitted: July 22, 1998; Accepted: March 29, 1999

Proofs received from author(s): December 27, 1999 